\title{
STOSUNEK CARATU DO POLSKIEJ DZIALALNOŚCI DOBROCZYNNEJ W WILNIE W I POLOWIE XIX WIEKU
}

\} \begin{array} { l } { \text { ie budzi wątpliwości fakt, że filantropia w pierwszej połowie XIX w. } } \\ { \text { stała się modna wśród elit. Arystokracja i ziemiaństwo żyły w przeświad- } } \\ { \text { czeniu o własnej szczególnej pozycji w społeczeństwie, która wiązała } } \end{array} się z wieloma „obowiązkami”. Jednym z nich była odpowiedzialność za edukację i kondycję niższych warstw społecznych, w szczególności zaś za losy ludzi najuboższych. Zewnętrznym przejawem realizacji tego obowiązku była przynależność do towarzystw dobroczynnych, fundowanie stypendiów dla ubogiej zdolnej młodzieży, zapisy testamentowe na szpitale, przytułki i żłobki. Dotychczasowe uczestnictwo w różnego rodzaju spotkaniach towarzyskich zaczęto motywować potrzebami ubogich i sierot. I tak w dobrym tonie postrzegano pojawianie się na balach, maskaradach, loteriach, przedstawieniach teatralnych i koncertach organizowanych na cele dobroczynne. Członkostwo w organizacji dobroczynnej było swego rodzaju obowiązkiem towarzyskim. Czy władze carskie wychodziły naprzeciw tego rodzaju działalności? Czy podejmowane przez Polaków inicjatywy dobroczynne nie budziły podejrzliwości, czy podobnie jak wszelkie inne formy zrzeszania, postrzegano je jako niebezpieczne?

Finansowanie akcji charytatywnych przynosiło niewątpliwe profity towarzyskie. Nazwiska darczyńców pojawiały się w prasie, otrzymywali oni również tytuły honorowe i odznaczenia. W mowach pogrzebowych zawsze uwydatniano wątek życiorysu zmarłego związany z działalnością filantropijną. W zaangażowaniu społeczeństwa polskiego $\mathrm{w}$ akcję charytatywną nie bez znaczenia były też pobudki religijne - uczynki miłosierne wobec bliźnich.

Filantropia stanowiąca $\mathrm{w}$ sferach wyższych swoistą nobilitację i podnosząca prestiż jej członków już w drugiej połowie XVIII w. uplasowała się na ważnym miejscu w dyskusjach filozoficznych i politycznych, co miało niebagatelny wpływ na kierunki działalności społecznej państw. Programy humanitarystów, których szczególna ekspansja miała miejsce w epoce oświecenia, w nędzy i cierpieniu widziały wstydliwą chorobę, której nie można zaradzić opierając się jedynie na 
religijnej tradycji jałmużny i miłosierdzia ${ }^{1}$. Przyczyna tego tkwiła w zmianie stosunków ekonomicznych na zachodzie Europy, gdzie pauperyzm stał się zjawiskiem masowym, wymykał się spod kontroli i wymagał interwencji państwa²

Największy zasięg interwencjonizmu państwa w dziedzinie opieki nad ubogimi miał miejsce we Francji (wpływ postępowych zasad rewolucji francuskiej, hasła encyklopedystów). Francja objęła kontrolę nad instytucjami dobroczynności, będącymi dotychczas w gestii samorządów miejskich i osób prywatnych ${ }^{3}$. W Anglii dobroczynność pozostawała w sferze prywatnej, ponieważ doktryna państwa liberalnego ograniczała ingerencję rządu w system opieki. Do 1834 r., kiedy to wprowadzono ,nowe prawo ubogich”, to gminy miały obowiązek udzielania wsparcia swoim mieszkańcom. Po 1834 r. zaostrzono kontrolę nad ubogimi, powołano rady opiekuńcze, które od 1847 r. podlegały kontroli ministerialnej. Podobnie w Prusach i Austrii główny ciężar opieki ponosiły gminy ${ }^{4}$.

Działalność Rosji w sferze opieki społecznej nie przedstawia się imponująco. Uboga jest również literatura dotycząca tego przedmiotu. Pierwszym carem, który zatwierdził bardzo ograniczony program pomocy ubogim był Fiodor Aleksiejewicz. Dopiero Katarzyna II w wydanym w 1775 r. „Statucie do zarządzania Guberniami Imperium Wszechrosyjskiego" położyła trwałe podwaliny pod system opieki społecznej, który przetrwał cały XIX w. Na jego strukturze swoją działalność w tej dziedzinie rozwijał Paweł I, Aleksander I i Mikołaj I. Statut Katarzyny przewidywał powołanie w każdej guberni tzw. Izb Opieki Społecznej, których zakres działania miał być bardzo rozległy. Izby miały kontrolować szkoły ludowe, sierocińce, przytułki, szpitale, domy dla nieuleczalnie chorych, domy dla chorych umysłowo oraz domy poprawy i pracy ${ }^{5}$. Zakrojony na szeroką skalę projekt napotkał przeszkody finansowe. Piętnaście tysięcy rubli, które każda gubernia miała przekazać Izbom z własnych dochodów było kroplą w morzu potrzeb, przy tak dużym zakresie działania. Powołane Izby utrzymywały się głównie z ofiar dobrowolnych od osób prywatnych ${ }^{6}$.

Aleksander I, oprócz 40 Izb założonych przez Katarzynę II, powołał jeszcze 13 takich placówek. W okresie jego panowania wzrosło zainteresowanie pomocą społeczną i zaczęła rozwijać się prywatna dobroczynność. W Wilnie Izbę Powszechnej Opieki powołano dopiero w 1808 r. Wcześniej opieka nad ubogimi

\footnotetext{
${ }^{1}$ Zob. szerzej: J. Radwan-Pragłowski, K. Frysztacki, Społeczne dzieje pomocy człowiekowi: od filantropii greckiej do pracy socjalnej, Warszawa 1996.

${ }^{2}$ B. Geremek, Litość i szubienica. Dzieje nędzy i miłosierdzia, Warszawa1989, s. 276.

${ }^{3}$ M. Piotrowska-Marchewa, Nędzarze i Filantropi. Problem ubóstwa w polskiej opinii publicznej w latach 1815-1863, Torun 2004 s. 89.

${ }^{4}$ Tamże, s. 94-96.

${ }^{5}$ A. Sokołow, Rosyjska dobroczynność w zwierciadle historii, Sankt-Petersburg-Warszawa, s. 19.

${ }^{6}$ O przeszłych Kommissyach Szpitalnych litewskich i o teraźnieyszey Magistraturze Powszechney Opieki w guberni litewsko-wileńskiey: Rzecz poprowadzona ogólnemi o tey materii uwagami $i$ wiadomościami, „Dzieje Dobroczynności Krajowej i Zagranicznej” (dalej: „DDKIZ”) 1820, s. 3-5.
} 
leżała przede wszystkim w gestii kościoła katolickiego. Katarzyna II pozostawiła na ziemiach włączonych do Cesarstwa podczas rozbiorów dawną organizację opieki społecznej, w której główną rolę odgrywały Wojewódzkie Komisje Szpitalne (powołane z inicjatywy Stanisława Augusta Poniatowskiego) ${ }^{7}$. W 1795 r. Komisja Wojewódzka została przemianowana na Komisję Szpitalną Litewską ${ }^{8}$.

Aleksander I popierał prywatne inicjatywy charytatywne na terenie swojego państwa, stanowiące podporę urządzeń państwowych. Przepojony hasłami oświecenia podejmował działania wobec poprawy losu poddanych i eksponował swoją opiekuńczą postawę wobec spauperyzowanych grup społecznych. Kreował w ten sposób wizerunek dobrego, dbającego o cały naród monarchy. Sam był głównym protektorem Towarzystwa Miłości Bliźniego ustanowionego w 1802 r. w Petersburgu' ${ }^{9}$. Podobnie jak w innych guberniach, także w guberni wileńskiej stał się rzecznikiem prywatnych fundacji na rzecz ubogich.

Nowo przyłączone do Rosji tzw. gubernie zachodnie (tereny dawnego Wielkiego Księstwa Litewskiego), znajdowały się na początku XIX w. w szczególnie trudnej sytuacji. O rozmiarach ubóstwa mogą świadczyć słowa Jana Korwina Kossakowskiego:

[...] w kraju naszym większa połowa ludzi żyje samym chlebem i roślinnym pokarmem, a wielu ubogim familiom, zbywa i na chlebie... a miłosierne fundusze nie są w stosunku do liczby ubogich, i przy największej oszczędności ledwie ich mogą wyżywić ${ }^{10}$.

Wojny i nieurodzaj z lat 1805-1806 sprowadziły do Wilna wielu żebraków, którzy stracili dach nad głową i lepszej egzystencji poszukiwali w mieście. Władysław Zahorski przedstawiając obraz Wilna z początków XIX w. pisze o thumach żebraków i kalek na placach i przy kościołach, zawodzących religijne pieśni i natarczywie domagających się jałmużny ${ }^{11}$. System opieki społecznej nie zaspokajał rosnących potrzeb. Szpitale były przepełnione. Trafiali tu nie tylko chorzy, ale też inwalidzi wojenni, starcy i sieroty. W 1806 r. wojska powracające spod Austerlitz przyniosły do Wilna tyfus, płonicę i czerwonkę ${ }^{12}$. Między innymi wówczas zostały zarażone Siostry Mariawitki przy kościele św. Stefana, gdzie znajdował się szpital. W wileńskich szpitalach-przytułkach brakowało nie tylko leków

${ }^{7}$ Tamże, s. 3-6; K. Koralewski, Opieka społeczna. Dobroczynność publiczna, Warszawa 1918, s. 18.

${ }^{8}$ A. Adamowicz, Praktyczne postrzeżenia niektórych lekarzy, Wilno 1862, s. 174-175.

9 Urzadzenie Towarzystwa Imperatorskiego Człekolubnego, „DDKIZ” 1820, s. 41 - 45; 105-112.

${ }^{10}$ Biblioteka Litewskiej Akademii Nauk w Wilnie im. Wróblewskich (dalej: BLANW), sygn. L-19/1643, Mowa przy pierwszem zdaniu sprawy Towarzystwa Dobroczynności[...] przez Jana Korwina Kossakowskiego miana, Wilno 1808, s. 7-8.

${ }^{11}$ W. Zahorski, Wilno na początku XIX wieku, [b.m.r.w.], s. 275.

${ }^{12}$ Tenże, Zarys dziejów Cesarskiego Towarzystwa Lekarskiego w Wilnie (1805-1897), Warszawa 1898, s. 31-40; zob. szerzej: M. Korybut-Marciniak, Stan zdrowotny mieszkańców Wilna w początkach XIX wieku, „Biuletyn Historii Pogranicza” 2012, nr 12, s. 15-26. 
i łóżek. Nie było tam często pożywienia, a zimą deficyt środków finansowych uniemożliwiał ich ogrzanie ${ }^{13}$.

W celu przeciwdziałania rosnącemu ubóstwu biskup wileński Jan Nepomucen Kossakowski i profesor wydziału medycznego Cesarskiego Uniwersytetu Wileńskiego Józef Frank powołali w 1807 r. Wileńskie Towarzystwo Dobroczynności [dalej: WTD] ${ }^{14}$. Była to największa instytucja dobroczynna o charakterze polskim na Ziemiach Zabranych i pierwsze tego typu towarzystwo na ziemiach polskich.

Biskup Kossakowski - członek Izby Powszechnej Opieki - w 1806 r. otworzył księgę składek nowej organizacji (sam wpłacając 1000 rubli srebrnych), na którą wpisało się wielu znakomitych Polaków, m. in. Jan Śniadecki, Józef Sierakowski, Jerzy Tyszkiewicz, Ludwik Plater, Michał Romer ${ }^{15} .7$ kwietnia 1807 r. Towarzystwo liczące 22 członków zostało oficjalnie otwarte. Wysokie składki członkowskie spowodowały, że akces do Towarzystwa zgłaszali tylko najbogatsi - głównie członkowie dawnych rodów magnackich. Towarzystwo określiło w ustawie trzy obszary swoich działań: pierwszy obejmował pomoc żywnościową i finansową najuboższym mieszkańcom Wilna, drugi pomoc prawną ubogim w dochodzeniu swoich racji, trzeci zaś pomoc medyczną. Car Aleksander I bardzo szybko zatwierdził statut WTD. Złożone przez biskupa Kossakowskiego w końcu grudnia 1807 r. na ręce generał-gubernatora Aleksandra Rimskiego-Korsakowa list i ustawy Towarzystwa zostały przez cara zatwierdzone dwoma reskryptami. Pierwszy, adresowany do biskupa, podpisany został 14 lutego 1808 r., drugi, złożony na ręce gubernatora, datowany na 15 lutego $1808 \mathrm{r} .{ }^{16} \mathrm{~W}$ dowód przychylności wobec tej inicjatywy car przekazał do kasy WTD 10 tysięcy rubli (15 tysięcy jednorazowo otrzymywały Izby Powszechnej Opieki obejmujące całe gubernie; Towarzystwo ograniczało teren swojej działalności tylko do miasta Wilna). Inspirator instytucji dobroczynnej - Jan Nepomucen Kossakowski otrzymał brylanty do Orderu św. Aleksandra Newskiego ${ }^{17}$.

Mowa biskupa Kossakowskiego przy pierwszym zdaniu sprawy z działalności Towarzystwa z dnia 14 maja 1808 r. (3 miesiące po zatwierdzeniu ustaw przez cara) podkreśla przychylny stosunek monarchy do wszelkich organizacji przeciwdziałających nędzy. Kossakowski wspominał w niej powstałe w 1804 r. w Petersburgu towarzystwo „Lekarsko-Filantropiczne”, na które rząd

${ }^{13}$ W. Zahorski, Wilno..., s. 284.

${ }^{14}$ Zob. M. Korybut-Marciniak, Dobroczynne Wilno. Pomoc ubogim i potrzebujacym $w$ Wilnie w pierwszej połowie XIX wieku, Olsztyn 2012, s. 91-240; H. Markiewicz, Działalność opiekuńczo-wychowawcza Wileńskiego Towarzystwa Dobroczynności 1807-1830, Warszawa 2010; K. Rawicz, Wileńskie Towarzystwo Dobroczynności w stuletnia rocznice, Wilno 1907.

${ }^{15} \mathrm{~K}$. Rawicz, dz. cyt., s. 12.

${ }^{16}$ Litewskie Państwowe Archiwum Historyczne (dalej: LPAH), Wileńskie Towarzystwo Dobroczynności, Reskrypt Najjaśniejszego Imperatora Wszech Rossyi Aleksandra I, F. 1472, inw. 1, sygn. 1, k. 1-3.

${ }^{17}$ Tamże, k. 3. 
przeznaczał corocznie 24 tysiące rubli ${ }^{18}$. Cytował też słowa pochwalne Aleksandra wobec Towarzystwa Hamburskiego, które car podawał jako wzór:

[...] Życzeniem jest moiem, aby ten przykład był naśladowany [...], żebym zaś pokazał, ile mają prawa do serca mego, nieszczęśliwe losu ofiary, biorę pod szczególną i osobistą opiekę, zaprowadzające się w stolicy moiey, nowe Towarzystwa Dobroczynne, równie iak inne wszystkie iakie bez wątpienia za ich przykładem, w narodzie tak dla mnie ukochanym, na który przyrodzenie, wszystkie swe dary wylało [...], zaprowadzone na ratunek bliźniego zostaną ${ }^{19}$.

Główni organizatorzy WTD - Frank i Kossakowski - powołując Towarzystwo zdawali sobie sprawę, że będzie to instytucja popierana przez cesarza, zwłaszcza w tak trudnym okresie dla Wilna, które stało na szlaku przemarszów tysięcy żołnierzy, przynoszących ze sobą choroby i zajmujących miejsca w szpitalach. W mowie Kossakowskiego czytamy dalej:

[...] Nayiaśniejszy Monarcha zalecił mi nayłaskawiej oznajmić wszystkim Towarzystwa członkom, że na szczególnieyszą Nayiaśniejszego Monarchy zasłużyli przychylnośćco

Członków do zainicjowanego towarzystwa poszukiwano pośród najbogatszej części społeczeństwa ziem zabranych. Opłata członkowska w wysokości 30 rubli srebrnych (200 zł polskich) - była prawie dwukrotnie wyższa niż w powołanym 7 lat później Towarzystwie Warszawskim (10,8 rubli srebrnych - 72 zł $)^{21}$. Pamiętajmy, że większość przedstawicieli polskiej warstwy arystokratycznej na Litwie swoje nadzieje polityczne pokładała w Petersburgu. Rosji bardzo zależało na tym poparciu w obliczu konfrontacji z napoleońską Francją. WTD miało być formą zbliżenia Polaków do cara, który dzięki jego protekcji kreował wizerunek dobrego ojca, dbającego o wszystkich mieszkańców swojego kraju. I tak na listach członków znaleźli się czołowi działacze orientacji prorosyjskiej - Michał Ogiński, Tomasz Wawrzecki, Adam Jerzy Czartoryski i inni ${ }^{22}$.

Na listach członków i darczyńców, obok Polaków (znalazło się tu wielu gorliwych patriotów), odnajdujemy wielu Rosjan zajmujących wysokie stanowiska w hierarchii administracji gubernialnej. Osobą, która objęła honorowy patronat nad WTD był generał-gubernator Aleksander Rimski-Korsakow. Kossakowski podkreślał, że to dzięki jego staraniom car przyjął Towarzystwo pod swoją opiekę. Rimski-Korsakow nie tylko swoim imieniem i regularnymi opłatami członkowskimi zaznaczał swoją obecność w WTD, lecz brał też czynny udział w jego

\footnotetext{
${ }^{18}$ Mowa przy pierwszym zdawaniu sprawy Towarzystwa Dobroczynności [...] przez Jana Korwina Kossakowskiego miana, Wilno 1808, s. 12-13.

${ }^{19}$ Tamże, s. 15-16.

${ }^{20}$ Tamże, s. 20.

${ }^{21}$ E. Mazur, Dobroczynność w Warszawie w XIX wieku, Warszawa 1999, s. 20.

${ }^{22}$ LPAH, F 1472, inw. 1, sygn. 1, Ustawy Towarzystwa Dobroczynności, k. 11-12.
} 
pracach. Jego autorytet pomagał WTD w pozyskiwaniu funduszy. Świadczyć o tym może list Towarzystwa do profesora Tomasza Życkiego, który przekazał na ubogich ponad 13,5 tysiąca rubli srebrnych - niestety w formie długu marszałka powiatu wileńskiego Melchiora Włodkowicza. Korsakow zobowiązał się pomóc Towarzystwu w odzyskaniu gotówki z tego daru ${ }^{23}$.

Stanisław Morawski przedstawia Rimskiego-Korsakowa jako człowieka o nieposzlakowanej uczciwości, sprawiedliwego i nieprzekupnego. Przytacza zabawną historię związaną z WTD. Prałat Stefan Pusłowski wraz ze swoim bratem, marszałkiem słonimskim Wojciechem Pusłowskim, potrzebowali poparcia Korsakowa w sprawie wyłączenia administracji funduszów bogatego klasztoru Kartuzów. Chcąc zapewnić znanymi sobie sposobami przychylność urzędnika rosyjskiego, postanowili dać łapówkę. Prałat zostawił na krześle w jego gabinecie 50 tysięcy rubli asygnacyjnych. Gdy Korsakow z niepokojem zapytał co to jest, Pusłowski odrzekł, że to ofiara dla gubernatora. Zadowolony z pomyślnych negocjacji prałat został zaskoczony informacją w porannym „Kurierze Litewskim”:

JW Generał Gubernator Rymski-Korsakow, oświadcza w imieniu ubogich i kalek tego zakładu publiczne podziękowanie za ofiarę przez JW. Pusłowskiego, prałata Kapituły wileńskiej, w ilości 50 tysięcy rubli na rzecz tegoż Towarzystwa w dniu wczorajszym wspaniale przyniesioną ${ }^{24}$.

Rachunek roczny przychodu i rozchodu kasy Towarzystwa za rok 1825 zawiera informację o tej wpłacie z następującą adnotacją:

Suma przez prałata Pusłowskiego na dobre uczynki przeznaczona, a przez JW. Gubernatora Wojennego Litewskiego Rimskiego-Korsakowa na fundusz Towarzystwa oddana ${ }^{25}$.

Swoją pomoc Towarzystwu ofiarowywały również damy, dla których wzorem była Maria Fiodorowna (Dorota Augusta) - druga żona cara Pawła I, matka Aleksandra I i Mikołaja I. Paweł I 12 maja 1797 r. podpisał osobiste polecenie skierowane do Senatu, w którym naczelne zwierzchnictwo nad moskiewskimi i petersburskimi zakładami wychowawczymi przekazał właśnie jej. Przejęła ona pod swą całkowitą opiekę jedyną wówczas szkołę wyższą dla kobiet - Towarzystwem Wychowania Szlachetnych Dziewczą ${ }^{26}$. Z czasem założyła całą sieć szkół żeńskich i zakładów wychowawczych w ramach tzw. Urzędu Instytucji Imperatorowej Marii. Urząd ten funkcjonował także po jej śmierci. Za panowania

${ }^{23}$ BLANW, sygn. F 273-1799, Wileńskie Towarzystwo Dobroczynności [...], Do Wielmożnego JPana Tomasza Życkiego,[ br. pag.].

${ }^{24}$ S. Morawski, Kilka lat młodości mojej w Wilnie, 1818-1825, Warszawa 1959, s. 167-169.

${ }^{25}$ Rachunek roczny przychodu i rozchodu kassy Wileńskiego Towarzystwa Dobroczynności od dnia 1 stycznia 1825 do dnia ostatniego miesiąca grudnia tegoż roku, Wilno 1826.

${ }^{26}$ A. Sokołow, dz. cyt., s. 33. 
Mikołaja I zatwierdzono przepisy dotyczące działalności przytułków dla dzieci w ramach tej instytucji ${ }^{27}$.

Kobiety zgodnie z ustawami WTD nie mogły być członkami Towarzystwa. Przewidziano dla nich funkcje pomocnicze - organizowanie kwesty wielkanocnej, loterii, zabaw. Z czasem panie wzorem protektorki ubogich w Rosji - cesarzowej matki - zaangażowały się w działalność utworzonego przez Franka w 1809 r. Instytutu Macierzyństwa. Instytut został powołany w ramach III wydziału w celu ratowania noworodków, ubogich matek, wśród których brak pożywienia i odpowiednich warunków higienicznych powodował wysoką śmiertelność. Miał on również ograniczyć liczbę podrzutków, którym brakowało miejsca w szpitalu Dzieciątka Jezus. Opiekunkami Instytutu zostały: żona Generał-Gubernatora Maria Bennigsenowa jako prezydentka i hrabina Kossakowska oraz Krystyna Frank (sekretarz) ${ }^{28}$.

Hołdując modzie rozpowszechnionej wśród elit, w kwestach wielkanocnych i loteriach na rzecz ubogich brały udział znane w towarzystwie wileńskim damy. I tak w sprawozdaniach posiedzeń publicznych WTD odnajdujemy podziękowania dla generałowej Julii Łobarzewskiej z Narbuttów - znanej z romansu z Michałem Kutuzowem $^{29}$; Anny Chrapowickiej z Radziwiłłów ${ }^{30}$; hrabiny Doroty Łopacińskiej z Morykonich, będącej damą dworu cesarskiego, która brała również udział w towarzystwie dam szyjących ubrania dla ubogich w salonie księżnej Czetwertyńskiej ${ }^{31}$; Pauliny Bobiatyńskiej - żony wicegubernatora Wilna w latach 1813-1816 $6^{32}$; Karoliny Hornowej - żony Piotra Horna, gubernatora cywilnego wileńskiego ${ }^{33}$; Zofii Choiseul-Gauffier z Tyzenhauzów - przyjaciółce Aleksandra I; Anieli Kołkowskiej z Podberskich - przyjaciółce księcia Mikołaja Dołgorukowa ${ }^{34}$. Damy te, czołowe postacie życia towarzyskiego Wilna, nie angażowałyby się w tego typu działalność, gdyby poparcie caratu dla niej budziło najmniejsze wątpliwości ${ }^{35}$.

O pozytywnym stosunku rządu rosyjskiego do polskiej działalności dobroczynnej świadczą różne fundacje, jakimi monarcha wspierał szpitale i zakony zajmujące się posługą najuboższych. Przykładem może być ukaz cara, uposażający zgromadzenie sióstr miłosierdzia, które prowadziły szpital Sawicz i szpital Dzieciątka Jezus w dochody z dwóch starostw: międzyrzeckiego i żosielskiego

${ }^{27}$ Tamże , s. 33-34.

${ }^{28}$ M. Korybut-Marciniak, Dobroczynne..., s. 153-157

${ }^{29}$ S. Morawski, dz. cyt., s. 33.

${ }^{30}$ Tamże, s. 307-309.

${ }^{31}$ G. Puzynina, W Wilnie i na dworach litewskich. Pamiętnik z lat 1815-1843, Wilno 1928 [reprint, Kraków 1990], s. 64.

${ }^{32}$ Morawski, dz. cyt., s. 149.

${ }^{33}$ Tamże, s. 567.

${ }^{34}$ Tamże, s. 594-597.

${ }^{35} \mathrm{O}$ działalności dobroczynnej kobiet w Wilnie zob. szerzej: M. Korybut-Marciniak, Wileńskie damy dobroczynne w pierwszych dekadach XIX wieku - motywacje, działania, postawy, [w:] Życie prywatne Polaków w XIX wieku. „Portret kobiecy” - Polki realiach epoki, t. I, pod red. M. Korybut-Marciniak i M. Zbrzeźniak, Łódź-Olsztyn 2014, s. 39-56. 
w powiecie trockim, czy ukaz z 1805 r. zlecający Izbie Skarbowej Litewsko-Wileńskiej przekazanie kwoty 498 rubli srebrnych na utrzymania i wychowanie ubogich dziewcząt, którym klasztor dawał schronienie ${ }^{36}$.

Do końca panowania Aleksandra I jego stosunek do działalności dobroczynnej nie uległ zmianie. Podczas swojego pobytu w Wilnie w 1812 r. (26 kwietnia 26 czerwca), której celem było pozyskanie Polaków przeciw Napoleonowi, wspomógł kwestę wielkanocną kwotą 600 czerwonych złotych ${ }^{37}$. Informacji o wizycie w domu Towarzystwa nie odnajdujemy. Aleksander I uczestniczył w balach, organizował rekrutów i zaopatrzenie dla swojej armii. Sprawy dobroczynności $\mathrm{z}$ wiadomych względów zeszły na boczne tory ${ }^{38}$. Kolejna wizyta cara w Wilnie miała miejsce w grudniu 1812 r. Wówczas, jak wspomina Michał Kleofas Ogiński, car zajął się oczyszczaniem miasta w celu powstrzymania epidemii. Lata 1812-1816 były bardzo trudne dla Towarzystwa, ponieważ w jego domu podczas wojny urządzono lazaret. Dochody spadły drastycznie - wielu członków wyjechało, nie weszły do budżetu procenty od kapitałów, a wsparcia pieniężnego udzielano nie tylko cywilom, ale też jeńcom wojennym (w 1815 r. wsparto 657 jeńców) ${ }^{39}$. Dyrektor domu, ksiądz Alojzy Korzeniowski, chcąc zapewnić środki finansowe w tym trudnym czasie, zorganizował wypiekanie sucharów, które sprzedawano armii rosyjskiej (jeńcom francuskim dawano je bezpłatnie) ${ }^{40}$. W roku 1815 Aleksander przybył z wizytą do domu Towarzystwa. Dla jego administracji był to wydatek nadzwyczajny - zorganizowano obiad dla wszystkich ubogich w mieście, a w żywność zaopatrzono 600 więźniów. Sprawozdanie z posiedzenia publicznego WTD nie wspomina o żadnych ofiarach poczynionych przez cara. Mimo to, świadczy ona o dalszym poparciu. Z pewnością wpłynęła ona na odrodzenie tej organizacji i akces nowych członków. Faktycznie w latach 1815-1816 odnotowujemy wzrost dochodów, remonty w domu, odnowienie i rozbudowę fabryki i utworzenie sklepu. Towarzystwo w przeciągu 2 lat podniosło się z upadku, grożącego zamknięciem domu (w 1813 r. opłatę członkowską uiściło tylko 13 osób) ${ }^{41}$.

Kolejną wizytę w Wilnie monarcha złożył we wrześniu 1819 r. 17 września odwiedził wówczas dom dobroczynności. Osobiście oglądał „fabrykę ubogich”, w którym produkowano różnego rodzaju materiały, szkołę wzajemnego nauczania,

\footnotetext{
${ }^{36}$ Nadanie starostw międzyrzeckiego i osielskiego dla szpitalów Sióstr Miłosierdzia $w$ Wilnie, „DDKIZ” 1820, s. 297-298; Naznaczenie z gabinetu monarszego corocznej wpłaty na fundusz Sióstr Mariawitek w Wilnie, „DDKIZ” 1820, s. 298-299.

${ }^{37}$ BLANW, sygn. L-19/1622/1817, Posiedzenie Publiczne Wileńskiego Towarzystwa Dobroczynności odbyte w Wilnie dnia 16 Grudnia 1817 roku.

${ }^{38}$ J. Iwaszkiewicz, Litwa w 1812 roku, Wilno 1912, s. 64-68.

${ }^{39}$ BLANW, sygn. L-19/1410/1817, Rachunek roczny przychodu ... [ za rok 1817].

${ }^{40} \mathrm{~J}$. Iwaszkiewicz, dz. cyt., s. 211.

${ }^{41}$ M. Korybut-Marciniak, Dobroczynne..., s. 117-131.
} 
interesował się wyżywieniem podopiecznych WTD, opieką lekarską, jaką im oferowano ${ }^{42}$.

W 1819 r. z nową inicjatywą wystąpił gubernator Rimski-Korsakow. W celu pozyskania dodatkowych środków na ubogich poddał pomysł wydawania w Wilnie pisma na wzór organu prasowego Towarzystwa Człekolubnego w Petersburgu („,Rosyjski Inwalida”). Zdawał sobie sprawę, że przedruk tego periodyku w języku polskim nie spotka się z zainteresowaniem wśród Polaków, dlatego wyznaczył osobiście komitet redakcyjny i powołał wychodzący do stycznia 1820 r. miesięcznik „Dzieje Dobroczynności Krajowej i Zagranicznej”43.

Przemiany, do jakich doszło w ostatnich latach panowania Aleksandra I - polityczny odwrót cara od liberalizmu, ale również przeniesienie zainteresowania ku zagadnieniom religijnym i mistycznym, nie pozostał bez znaczenia dla Wileńskiego Towarzystwa Dobroczynności. W 1823 r. zaszły zmiany w komitecie redakcyjnym organu prasowego towarzystwa: Dziejów Dobroczynności (dotychczasowych redaktorów zastąpiły osoby duchowne) oraz w treści pisma, w którym przewagę zyskały artykuły o charakterze teologicznym. Nowy układ pisma wprowadzał dwa najważniejsze działy tematyczne: pierwszy nosił tytuł: „Dobroczynność duchowna współczesna”, drugi:" Wiadomości rzeczy duchownych"44. Reforma nie wyszła na dobre czasopismu, które ze względu na zmniejszenie liczby prenumeratorów i problemy finansowe zostało z końcem $1824 \mathrm{r}$. zamknięte ${ }^{45}$.

Rekapitulując powyższą analizę, politykę Aleksandra I wobec inicjatyw charytatywnych wychodzących ze środowisk polskich, można określić jako liberalną a nawet uprzywilejowaną. Car wyraźnie faworyzował WTD, w którym skupiło się wielu jego zwolenników. Należy tu jednak nadmienić, że środowisko zrzeszone w Towarzystwie nie było jednolite. Pojawiały się w nim nazwiska osób oddanych sprawie polskiej patriotów, antagonistów polityki prorosyjskiej, którzy angażując się w działania tej organizacji pragnęli poprawy sytuacji materialnej i oświatowej warstw niższych społeczeństwa polskiego. Aleksander I nie starał się ingerować w sprawy Towarzystwa - dawał mu całkowitą swobodę działania, niezależność od rządowych Izb Opieki Społecznej. W trudnych momentach swoją protekcją podtrzymywał jego egzystencję.

O stosunku Mikołaja I do polskich inicjatyw filantropijnych w Wilnie znajdujemy o wiele mniej informacji w źródłach. Przeprowadził on szereg reform aparatu państwowego, mających na celu objęcie kontroli tych dziedzin życia,

${ }^{42}$ Zagajenie sesji Publicznej Towarzystwa Dobroczynności [...] przez Prezydenta I wydzialu Michała Ogińskiego, „DDKIZ” 1820, s. 68.

${ }^{43}$ M. Korybut-Marciniak, Pierwsze polskie czasopismo poświęcone dobroczynności, „Biuletyn Historii Pogranicza" 2006, nr 7, s. 5-26.

${ }^{44}$ BLANW, sygn. F 273/1005, Ogłoszenie Komitetu Naukowego dotyczace zmian w Dziejach Dobroczynności w1823 roku, k. 1-3.

${ }^{45}$ M. Korybut-Marciniak, Pierwsze..., s. 24-25. 
w których mogły rodzić się niepożądane przez samowładcę idee. Kancelaria cesarska stała się wówczas jedną z najbardziej rozbudowanych instytucji państwowych. Dzieliła się od 1826 r. na cztery oddziały - czwarty został powołany do kontroli instytucji o charakterze charytatywnym ${ }^{46}$.

Mikołaj I oparł się w polityce społecznej na schemacie wypracowanym przez swoją babkę i brata. Powołał jeszcze cztery Izby Opieki Społecznej ${ }^{47}$. Jego rządy charakteryzował dalszy wzrost liczby towarzystw i instytucji służących pomocą warstwom spauperyzowanym. W $1840 \mathrm{r}$. car pożyczył ze skarbu 60 tys. rubli na założony w Petersburgu przez księcia Piotra Oldenburskiego przytułek dla dzieci ${ }^{48}$. W 1848 r. otwarto w Petersburgu pierwszy w Rosji żłobek ${ }^{49}$. Na początku lat 30. XIX w. zainicjował w większych miastach imperium sieć towarzystw opiekujących się więźniami. Cechą charakteryzującą te wszystkie przedsięwzięcia była ich ścisła kontrola rządowa.

W 1842 r. Mikołaj I przeprowadził reformę systemu pomocy społecznej - Izby Opieki Społecznej zostały zlikwidowane, a na ich miejsce powołano w każdej guberni Rady Opiekuńcze. Fundusze szpitali i przytułków zostały uznane za państwowe i przeszły pod zarząd Izby Dóbr Państwa. Rada wydzielała tym instytucjom roczne zapomogi proporcjonalne do ich udokumentowanych przychodów sprzed $1842 \mathrm{r}^{50}$

W pierwszej dekadzie panowania Mikołaja I, w kwestii stosunku do polskich inicjatyw charytatywnych, których czołowym przykładem w Wilnie było WTD, nie odnotowujemy większych zmian. Przychody towarzystwa utrzymywały się na mniej więcej równym poziomie $-8-14$ tys. rubli srebrnych. W 1831 r., co prawda składkę uiściło tylko trzynastu członków, ale już w 1832 r. dwudziestu dwóch, co było normą ${ }^{51}$. Powstanie listopadowe nie wywołało nagłych zmian w WTD, jednak przeglądając zeznania rachunkowe dostrzegalna jest pewna ewolucja. Przede wszystkim wśród „dobroczyńców” mamy coraz więcej nazwisk rosyjskich, po drugie, nie znajdujemy już dużych, jednorazowych zapisów, co miało miejsce w okresie przedpowstaniowym, ani tzw. dochodów nadzwyczajnych (teatr, sprzedaż artykułów ze sklepu WTD, kwesty). Również sam charakter rachunków budzi podejrzenia, co do uczciwego wydatkowania środków na pomoc ubogim. Skrócono ich formę - kwoty przychodu były równe kwotom rozchodu (zazwyczaj niewielkie fundusze drobiazgowo rozliczne w latach wcześniejszych pozostawały w budżecie towarzystwa na rok następny). Może to świadczyć o słabszej kondycji

${ }^{46}$ L. Bazylow, Historia Rosji, Wrocław-Warszawa-Kraków-Gdańsk-Łódź, s. 282-283; W. Śliwowska, Mikołaj I i jego czasy (1825-1855), Warszawa 1965.

${ }^{47}$ A. Sokołow, dz. cyt., s. 34.

${ }^{48}$ Tamże, s. 47.

${ }^{49}$ Tamże, s. 45.

${ }^{50}$ A. Adamowicz, dz. cyt., s. 175.

${ }^{51}$ Rachunek roczny Wileńskiego Towarzystwa Dobroczynności z 1830 roku, Wilno 1831; Rachunek roczny Wileńskiego Towarzystwa Dobroczynności z 1831 roku, Wilno 1832. 
finansowej organizacji - wydatki pochłaniały cały dochód i nie wystarczały na opatrywanie wszystkich ubogich lub, co bardziej prawdopodobne, o nieuczciwości urzędników. Rachunki sprawiają wrażenie mniej rzetelnych, wpisywane sumy pieniężne były w nich zaokrąglane. $Z$ pewnością nie umknęło to uwadze wilnian i miało wpływ na zmniejszenie zaufania społecznego wobec WTD.

Powołane przez cara Towarzystwa Opieki Więzień nie ominęły także Wilna. W 1834 r. ogłoszono ustawy towarzystwa, które za główny cel stawiało poprawę losu więźniów poprzez ustawiczny dozór wszystkich zakładów penitencjarnych przez administrację towarzystwa. Nacisk kładziono na poprawę moralności i wpajanie postaw chrześcijańskiej pobożności - tutaj liczono na współpracę z kapłanami $^{52}$. Inicjatywa wyszła od tronu i była mu całkowicie podległa. Prezydenta towarzystwa wybierał cesarz (w Wilnie został nim Mikołaj Dołgorukow - generał-gubernator). Jak czytamy w artykule III „Towarzystwo będzie pod najwyższą protekcją Cesarza Jegomości”"53. W towarzystwie wyznaczono też komitet żeński, którego zadaniem było nadzorowanie więzień dla kobiet (złożony był oczywiście z wileńskich dam). O działalności Towarzystwa nie odnajdujemy już później żadnej wzmianki. Być może raziła Polaków obłuda cesarza, który chciał pokazać swoją wielkoduszność wobec osób, które sam pozbawił wolności i majątku, stąd projekt nie zyskał społecznego poparcia.

Nieco inaczej przedstawiało się poparcie dla przedsięwzięcia Księżnej Elżbiety Dołgorukowej. Założyła ona w 1838 r. przytułek dla ubogich dzieci, składając na ten cel 300 rubli srebrnych. Władze zatwierdziły tę dobroczynną inicjatywę 1 lutego 1839 r., sam car Mikołaj I ofiarował dwupiętrowy dom na ulicy Ostrobramskiej i niecałe 900 rubli na pierwsze potrzeby. Dołgorukowa została przewodniczącą przytułku, a damy z towarzystwa zaangażowały się w zbieranie składek..$^{54}$ Jeden dom ochrony dla sierot okazał się niewystarczający. W 1844 r. założono podobny na Zarzeczu. W połowie lat czterdziestych carat przejął nad tymi placówkami pełną kontrolę tworząc „Komitet Ochrony”, którego prezydentem miał być każdorazowy gubernator cywilny, członkami zaś marszałek gubernialny oraz prezydenci Izby Skarbowej i Dóbr Państwa ${ }^{55}$

Carat systematycznie rozciągał nadzór nad wszystkimi inicjatywami społecznymi. Przyszła ostatecznie pora na rozprawienie się z WTD, które cały czas było największą tego rodzaju organizacją w guberni wileńskiej, ciągle całkowicie niezależną od władz, ponadto zrzeszającą wielu Polaków. Ten brak kontroli organizacyjnej i finansowej nie odpowiadał linii politycznej Mikołaja I. Pierwsze oznaki

${ }^{52} \mathrm{~W}$ dniu 28 grudnia 1834 r. biskup wileński Jędrzej Benedykt Kłągiewicz zwrócił się pisemnie do zakonów żeńskich w Wilnie, by wspomogły Towarzystwo Opieki Więzień dostarczając sprzętów niezbędnych do wyposażenia kaplicy przeznaczonej dla więźniów: zob.: BLAN, sygn. F 43-24533, Biskup [...] Jędrzej Benedykt Kłagiewicz Do Wielebnych Panien Zakonnych klasztorów wileńskich [b. pag.].

${ }^{53}$ Prawidła dla Towarzystwa Opieki Więzień, Wilno 1834.

${ }^{54}$ A. Adamowicz, dz. cyt., s. 187.

${ }^{55}$ Tamże, s. 187-188. 
zamiaru ograniczenia niezależności towarzystwa można dostrzec już w $1837 \mathrm{r}$. Gabriela Puzynina w swoich pamiętnikach wspomina wizytę Mikołaja I w WTD, kiedy vice-prezydentem był jej ojciec - Adam Günther ${ }^{56}$. Podczas tej wizyty jej uwagę zwróciło napięcie ojca związane $\mathrm{z}$ kwestią odebrania towarzystwu funduszy $^{57}$. Być może już wtedy dyskutowano nad jakąś formą nadzoru nad WTD. Jednakże dopiero w 1844 r. doszło do ostatecznego szturmu.

Generał-gubernator Fiodor Jakowlewicz Mirkowicz w piśmie urzędowym zawiadomił ówczesnego prezesa towarzystwa - biskupa Jana Cywińskiego, że WTD będzie podlegać nadzorowi Rady Opiekuńczej. Biskup z racji swojej funkcji w towarzystwie miał wejść w skład rady, której zadaniem było przeanalizowanie dotychczasowej działalności WTD i ustalenie, jakie zmiany organizacyjne są niezbędne. Rada Opiekuńcza zażądała szczegółowego opisania zakładu, aby móc podjąć decyzje, co do koniecznych reform. Dla towarzystwa taka zmiana oznaczała przede wszystkim utratę wielu funduszy (część zapisów na rzecz ubogich miała zastrzeżenia dotyczące niezależności finansowej zakładu); dotyczyło to min. domu dobroczynności - pałacu Januszowskiego, zapisanego przez Dominika Radziwiłła. Prezydent Cywiński starał się dowieść urzędnikom Rady Opiekuńczej bezzasadność zmian, twierdząc, że na połączeniu ucierpią ubodzy, ponieważ formalności biurokratyczne będą przeszkodą w udzielaniu im wsparcia. Taka argumentacja nie przemawiała do gubernatora Mirkowicza ${ }^{58}$. Rada Opiekuńcza na posiedzeniu mającym miejsce pod koniec grudnia 1844 r., głucha na głosy protestujących, uchwaliła szereg „udoskonaleń” w czynnościach WTD, co równało się z rozdysponowaniem funduszy organizacji ${ }^{59}$. Wszystkie wydatki przekraczające kwotę 300 rubli wymagały zgody Rady; zastrzegała ona sobie kontrolę ksiąg przychodu i rozchodu oraz comiesięczne sprawozdania działalności WTD. Wprowadzone zmiany zmierzały nieuchronnie do podporządkowania towarzystwa i godziły w jego ustawy z 1808 r. Rozumiejąc to, biskup Cywiński odmówił podpisania protokołu z sesji Rady, na której zapadły te wszystkie przekreślające samodzielny byt towarzystwa postanowienia. Zakłopotany gubernator postanowił zwołać kolejną sesję, na której WTD otrzymało szansę przedstawienia własnego projektu reform, uwzględniającego oczywiście żądania Rady. Ostatecznie w spór zaangażował się Minister Spraw Wewnętrznych Lew Aleksiejewicz Perowskij, który polecił Radzie Opiekuńczej opracowanie nowego projektu ustawy dla WTD. Została ona zatwierdzona 18 kwietnia 1847 r. WTD, nie zmieniając nazwy, utraciło niezależność funkcjonowania. Od tej pory nawet wybór

${ }^{56}$ Prezydentem był wówczas biskup Jędrzej Kłągiewicz.

${ }^{57}$ G. Puzynina, $d z$. cyt., s. 238.

${ }^{58}$ K. Rawicz, dz. cyt., s. 46-48.

59 „Udoskonalenia” dotyczyły stworzenia szpitala (hospicjum) dla nieuleczalnie chorych na 50 łóżek, szpitala dla inwalidów na 200 łóżek, do którego przyjmowano by nie tylko ubogich, ale też pacjentów, którzy opłacaliby w nim swój pobyt, zamknięcia szkoły wzajemnego nauczania; K. Rawicz, dz. cyt., s. 48. 
prezydenta warunkowała przychylność Rady ${ }^{60}$. Najważniejsza z polskich instytucji dobroczynnych na ziemiach zabranych została podporządkowana caratowi. Jej tak długą - 40 letnią egzystencję na niezmienionych zasadach należy tłumaczyć wcześniejszym poparciem Aleksandra I. Niestety rezerwy tego poparcia, które w okresie walki WTD o niezależność (1844-1847) stały się głównym argumentem jego obrony, musiały wyczerpać się. Mikołaj I konsekwentnie realizując politykę podporządkowywania wszystkich przejawów niezależnej działalności tronowi, osiągnął swój cel.

W związku z tym, że zakony i zgromadzenia zakonne były do 1807 r. głównymi organizatorami pomocy ubogim w Wilnie, a po utworzeniu WTD również odgrywały znaczną rolę $\mathrm{w}$ tej dziedzinie, zasadna $\mathrm{w}$ tym miejscu jest krótka charakterystyka stosunku władz rosyjskich do ich działalności.

Za rządów Katarzyny II, ukazem z dnia 3 listopada 1798 r. został określony zakres działalności klasztorów żeńskich. Zobowiązano je do prowadzenia zakładów wychowawczych dla dziewcząt, przytułków oraz szpitali. W Wilnie wówczas tego typu działalność prowadził Zakon Sióstr Św. Łazarza (mariawitki), który w szpitalu Św. Łazarza opiekował się neofitkami oraz sierotami, prowadził też szkoły dla dziewczą ${ }^{61}$; zakon bonifratrów, który pod swoją pieczą miał szpital dla umysłowo chorych ${ }^{62}$; siostry miłosierdzia, które prowadziły szpital fundacji biskupa Bogusława Gosiewskiego na ulicy Sawicz, dom sierot i podrzutków (dom Dzieciątka Jezus) ufundowany przez księżną Jadwigę Ogińską i założony na Łukiszkach tzw. szpital generalny Św. Jakuba ${ }^{63}$.

Okres rządów Pawła I i Aleksandra I charakteryzował się stabilną polityką wobec zakonów i zgromadzeń zakonnych na ziemiach dawnego Wielkiego Księstwa Litewskiego. Władzę zwierzchnią nad klasztorami sprawowali biskupi diecezjalni, nadano im również samodzielność gospodarczą. Dopiero Mikołaj I przedsięwziął twardy kurs wobec tych instytucji ingerując $\mathrm{w}$ wewnętrzną organizację życia zakonnego. Na mocy ukazu z dnia 4 lutego 1830 r., wszystkie zakłady dobroczynne prowadzone przez klasztory lub zgromadzenia katolickie w Wilnie przechodziły pod bezpośredni zarząd Izby Powszechnej Opieki. Dotychczasowi właściciele przytułków i szpitali stali się od tego momentu jedynie ich użytkownikami ${ }^{64}$. Powstanie listopadowe przyniosło dalsze ograniczenie w działalności klasztorów, a w skutek ukazu z dnia 19 lipca 1832 r. część z nich uległo kasacie. Ostatecznym krokiem caratu, przypieczętowującym ich los był ukaz z 25 grudnia

\footnotetext{
${ }^{60}$ Tamże, s. 49-50.

${ }^{61}$ W. Zahorski, Kartka z dziejów dobroczynności, [w:] Znad Wilii i Niemna. Pamięci Adama Mickiewicza i Tomasza Zana w 50 rocznice ich zgonu, Wilno 1906, s. 75-77.

${ }^{62}$ Zob.: S. Rosiak, Bonifratrzy w Wilnie, Wilno 1928.

${ }^{63}$ Zob.: tenże, Prowincja Litewska Sióstr Miłosierdzia, Wilno 1933; M. Korybut-Marciniak, Dziatalność dobroczynna zakonów i zgromadzeń zakonnych w Wilnie w końcu XVII i I połowie XIX wieku, „Echa Przeszłości”, t. XI, 2010, s. 131-150.

${ }^{64}$ S. Rosiak, Prowincja ..., s. 34-37.
} 
1841 r., na podstawie którego wszystkie majątki ziemskie wyższego kleru katolickiego i klasztorów miały stać się własnością państwa. Zakony przechodziły na „pensje rządowe”. Klasztory podzielono na trzy kategorie, według których uzależnione było ich uposażenie przez rząd. Jedynie niewielka część została włączona do tzw. etatowych, czyli finansowanych przez państwo. Wszystkie pozostałe pozbawione możliwości utrzymania się przestały istnieć. Taki los spotkał zakłady mariawitek, bonifratrów i sióstr miłosierdzia ${ }^{65}$. Te ostatnie częściowo kontynuowały swoją działalność w łonie WTD. Siostry miłosierdzia swoją służbę towarzystwu świadczyły aż do 1888 r., w którym zmarła ostatnia z zakonnic.

Postawa caratu wobec polskich inicjatyw dobroczynnych w Wilnie była uzależniona od sytuacji politycznej. Ewaluowała od pełnej aprobaty za czasów Aleksandra I do podejrzliwość i niechęci za reakcyjnych rządów Mikołaja I. Dla Mikołaja I każda inicjatywa pochodząca z innej inspiracji niż jego własna była potencjalnym źródłem społecznych niepokojów. Tym bardziej, że filantropię często łączono z działalnością oświatową i patriotyczną. Należy podkreślić, że dobroczynność, która w pierwszej połowie XIX w. stała się towarzyskim wymogiem, pełniła rolę spoiwa różnych środowisk. Najlepszym tego dowodem jest przykład WTD. Odpowiadało to linii politycznej Aleksandra I, lecz stało się niebezpieczne dla jego następcy.

Obszar działalności dobroczynnej był często wykorzystywany jako grunt porozumienia z Polakami. Idea filantropii łagodziła wzajemne stosunki polsko-rosyjskie. W czasach wzmożonych represji stawała się tematem zastępczym - organizacja pomocy ubogim warstwom społecznym często pojawiała się na szpaltach „Tygodnika Petersburskiego” w 1831 i 1832 r. Był to temat wygodny, poglądy na temat pomocy ubogim stanowiły spoiwo społeczeństwa polskiego i rządu rosyjskiego, na tym obszarze nie było większych różnic poglądów. Polacy pragnęli jednak zachować na tym polu względną niezależność, carat zaś w drugiej połowie XIX wieku, zdeterminowany podejrzliwością, nie mógł sobie na to pozwolić.

${ }^{65}$ Tamże, s. $39-44$. 
Maria Korybut-Marciniak

\section{THE ATTITUDE OF THE TSARIST REGIME AGAINST THE POLISH CHARITABLE INITIATIVES IN VILNIUS IN THE FIRST HALF OF THE NINETEENTH CENTURY}

The attitude of the tsarist regime against the Polish charitable initiatives in Vilnius was dependent on the political situation. Has evolved with the full approval of the time of Alexander I of suspicion and resentment for the reactionary governments of Nicholas I. Alexander I supported the initiative to establish the Vilnius Charitable Society. Nicholas I in every Polish initiative saw the source of unrest. The more that philanthropy is often combined with educational and patriotic activities. It should be emphasized that the charity, which in the first half of the nineteenth century, has become a social requirement, act as a binder different backgrounds. The best example of this is the Vilnius Charitable Society. This corresponded to the political line of Alexander I, but it has become dangerous for Nicholas. Tsar Nicholas I took control of all philanthropic initiatives in the lands of the Lithuanian - Belarusian. 